\title{
An estimation of the total atmospheric pollution in Quetta (Pakistan) using solar data
}

\author{
Syed Zafar Ilyas $\cdot$ S. M. Nasir $\cdot$ T. N. Veziroglu
}

Published online: 24 July 2007

(C) Springer-Verlag 2007

Erratum to: Clean Techn Environ Policy

DOI 10.1007/s10098-007-0094-7

Unfortunately, this article received a wrong category title.

The correct title should be "Original Paper" and not

"Guest Column".

Please excuse the mistake.

The online version of the original article can be found under doi:10.1007/s10098-007-0094-7.

S. Z. Ilyas $(\bowtie) \cdot$ S. M. Nasir

Group of Renewable Energy, Department of Physics,

University of Balochistan, Quetta, Pakistan

e-mail: szilyas@yahoo.com; szilyas@hotmail.com

T. N. Veziroglu

Clean Energy Institute, Department of Mechanical Engineering,

University of Miami, Miami, FL, USA 